\title{
IMPROVING THE ORGANIZATION OF FOOD TRANSPORTATION BY ROAD TO SHOPPING CENTRES IN CONAKRY (GUINEA) BY OPTIMIZING SUPPLY CHAINS
}

Mohamed Kuruma, Alexey V. Kulikov

Volgograd State Technical University, Volgograd, Russia

\section{СОВЕРШЕНСТВОВАНИЕ ОРГАНИЗАЦИИ АВТОМОБИЛЬНЫХ ПЕРЕВОЗОК ПРОДУКТОВ ПИТАНИЯ В ТОРГОВЫЕ ЦЕНТРЫ КОНАКРИ (ГВИНЕЯ) ЗА СЧЕТ ОПТИМИЗАЦИИ ЦЕПОЧЕК ПОСТАВОК}

\author{
М. Курума, А. В. Куликов
}

Волгоградский государственный технический университет, Волгоград, Россия

\begin{abstract}
Like other countries in Sub-Saharan Africa, Guinea has to deal with the organization of the transport of food in these different markets throughout the country while optimizing and the cost of transport and the duration of the journey. To transport goods in good condition to achieve these goals there are the following factors: analysis of transported food, statistics of regional markets, analysis of the company Africa logistics through the types of perishable and non-perishable food transported by this company without forgetting analysis of the trade flows of Guinea.
\end{abstract}

Key words: transport, food, Guinea, Conakry, company Africa logistics, Guinea transport system
Аннотация. Как и другие страны Африки, расположенные к югу от Сахары, Гвинея должна заниматься организацией поставок продуктов питания на различные рынки страны, оптимизируя при этом транспортные расходы и продолжительность перевозок. Для сохранения грузов в хорошем состоянии нужно учитывать следующие факторы: характеристику перевозимых продуктов питания, статистику региональных рынков, классификацию продуктов питания на группы скоропортящихся и нескоропортящихся, перевозимых компанией Africa logistics, - и не забывать при этом анализировать эффективные торговые потоки Гвинеи

Ключевые слова: транспорт, продукты питания, Гвинея, Конакри, компания Africa logistics, транспортная система Гвинеи 


\section{Introduction}

Transport is one of the most important spheres of social production and is a branch of material production. All products of enterprises will be useful when they are delivered to the place of consumption. This is the great importance of transport. Cargo road transport plays an important role in solving the problems of full and timely satisfaction of the needs of the public economy and the population in transportation, in improving the efficiency and quality of the country's transport system. In the modern competitive struggle, an enterprise that effectively and continuously works to improve the transportation process has competitive advantages, which allows it to sell a larger volume of products, and by increasing the volume to increase its profit and strengthen its position in the market. Road transport in Guinea carries about $80 \%$ of the total volume of goods transported by all modes of transport. There is no alternative to motor transport when transporting expensive goods over short and medium distances, in retail trade, in industry, in production logistics systems, in the transport support of small businesses and in the maintenance of agricultural complexes.

The lack of a modern transport network hindered the development of the country. In total, the total length of the railway tracks is $1086 \mathrm{~km}$ (675 miles). The state single-track metre gauge railway from Conakry to Cancan 663 km (412 miles) was built in 1900 and 1914; it is in disrepair and can no longer withstand heavy rolling stock. In 1991, the railway was repaired with the help of France. A standard gauge railway track of about $112 \mathrm{~km}$ (70 miles) along this line between Conakry and Debele, near Kindia, connects the port. Has built and maintains a $144 \mathrm{~km}$ (89 miles) railway between the Fria mines and alumina works and the port of Conakry; Boke has built a 135 km (84 miles) railway that links the Sangaredi fields to the port of Kamsar. Of the $30500 \mathrm{~km}$ (18953 miles) of roads, about 5033 km (3 128 miles) were filled in with tarmac in 2002. In 1995; there were 23155 cars and 13000 trucks. In June 2020, there were 1620580 cars and 780000 trucks. According to the Vehicle Registration Service of the Republic of Guinea [1, 2].
Conakry has a natural deep-water harbour that handles foreign cargo (mainly bauxite and alumina and food). The modernization of the port is planned with the support of IDA, the African Development Bank and the Federal Republic of Germany (FRG). In 2001, there were 12 airports in Guinea, 5 of which had paved runways. Conakry-Gbessia Airport, serves international airliners. Gbessia, three small airfields in Labe, Cancan and Faranah, as well as a number of runways are served by the national carrier Air Guinea, which also operates flights to other cities in West Africa and in 1997 carried 36000 passengers on domestic and international flights. The transport system of Guinea includes the interaction of road, sea, rail and air transport.

By investing in the Conakry Port container terminal, Bollore Transport Logistics is transforming an infrastructure of strategic importance to the country into a huge development asset for shipowners and leading players in the Guinean economy.

The creation of the port of Kagbelen a few kilometres from Conakry, with direct access to the road and rail networks, creates a new multimodal hub serving the corridors in Mali and Burkina Faso. Offering attractive storage space, the Bollore Transport Logistics platform offers modern, fast and long-term transport and logistics solutions that meet the dual need for productivity and economic development in Guinea $[3,4]$.

\section{Object and methods}

The concept the essence of transport logistics and its role in the overall system of the Bollore group enterprise

In a broader sense, the concept of logistics can be interpreted as a modern methodology and methodology for managing flows of all interrelated types that arise in the course of economic activity as a single entity.

Thus, logistics considers the entire cycle of economic activity as a whole: from the selection of appropriate production tasks, determining effective methods of solving them, managing the application of these methods to the organization and management of sales processes and sales of goods. 
Although logistics considers the problem of managing economic activity in general, due to the different physical nature of the managed material and non-material flows, there are functional sections or areas of logistics management, for example:

- inventory logistics;

- transport logistics;

- procurement logistics;

- sales logistics;

- logistics of production processes;

- warehouse logistics;

- information logistics.

The main idea underlying the logistics approach to the organization and management of economic activities is integration. This is because the flows of materials, resources, finance, and information that exist independently at technically independent stages and stages of activity can be interconnected through a common management system, which can have a significant economic impact.

In general, logistics management answers the following questions:

- how to place orders for food products and plan a warehouse network;

- how to choose food products and equipment for its promotion;

- how to implement food planning;

- how to choose the structure and implementation of the internal food supply system and manage its functioning;
- how to perform dispatching and production control of food products;

- how to create an efficient food storage system; - how to account for and manage food stocks.

One of the most important functional sections of the general logistics science, directly related to the organization and management of the movement of food flows, is transport logistics. In the process of interaction, objects are moved: raw materials and materials from suppliers to manufacturers, finished products from the manufacturer to intermediaries and from them to end users. Consequently, it is necessary to ensure the physical movement of such goods in Guinea along the optimal route with the lowest cost. This is exactly what transport logistics does.

There are many definitions of the concepts of "transport logistics" and "transport":

- transport logistics - moving the required quantity of goods to the desired point, the optimal route within a certain time and at the lowest cost;

transportation - the movement of cargo by a vehicle using a specific technology in the supply chain.

The goal of transport logistics is to deliver the desired product of the required quality and quantity at the specified time and place with optimal costs (compliance with the 6 rules of logistics). The main tasks of transport logistics include [5-8]:

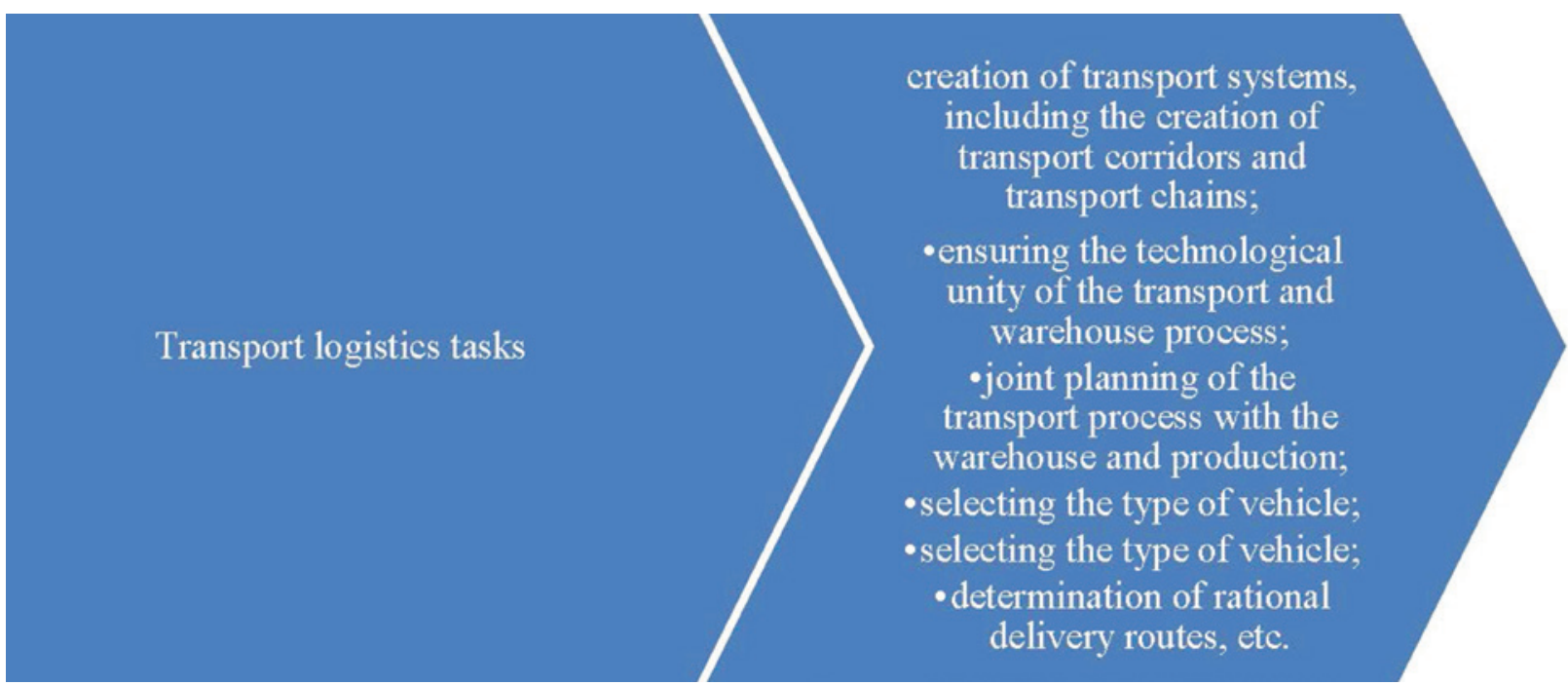

Fig. 1. Transport logistics tasks 
- choice of the type of transport (automobile, railway, air, etc.);

- choice of the method of transportation (type of transportation);

- selection of the carrier and other logistics partners;

- determination of rational delivery routes;

- ensuring the technological unity of the transport and warehouse process;

- optimization of transport process parameters

(increase of transport speed, reduction of fuel consumption, etc.).

Transport is a branch of material production that transports passengers and cargo. In the structure of public production, transport refers to the production of material services. Transport can be divided into two broad categories: public transport and non-public transport. The tasks of transport logistics are shown in fig. 1.

The following principles of transport logistics are distinguished: one of the first principles of transport logistics is its creation, analysis and improvement of food products based on the methodology of the general theory of cybernetic systems. The fact that the main thing in the transport process of food products is to take into account the needs of the market.

\section{Results/discussion}

In general, the availability of food in Guinea is determined by a combination of local production, as well as imports from regional and international markets. Despite the potential for agricultural production, domestic production is not sufficient to meet market demand. About 25 percent of the total demand for basic food is provided by imports, especially rice [4]. Rice is certainly a staple food in Guinea. Due to insufficient domestic production to meet demand, imports account for a significant proportion of the total amount of rice. Cassava is the second most important food item and the most important tuber consumed.

Food consumption based on the average consumption levels observed over the past fiveyears, as established by FAO/CCBS, it is estimated that per capita annual consumption in 2018 will be $175 \mathrm{~kg}$ of cereals, including $104 \mathrm{~kg}$ of milled rice, $34 \mathrm{~kg}$ of maize, $10 \mathrm{~kg}$ of wheat, and $27 \mathrm{~kg}$ of sorghum, millet and other cereals. Furthermore, since cassava is an important part of the national diet, it is assumed that 50 per cent of national cassava production (approximately $16 \mathrm{~kg}$ of cereal equivalent) is consumed per person per year. The remaining energy requirements and other necessary nutrients are assumed to come from the limited quantities of poultry, meat, sweet potatoes, vegetables, fruits, and other available commodities [3].

Forage use: the use of cereals to feed animals is very limited in the country. However, given the growing importance of the poultry sector in the country, some secondary cereals and roots are used in dietary supplements. Thus, it is estimated that $10 \%$ of corn, $5 \%$ of small grains and $25 \%$ of cassava are used for animal feed.

Seed requirements they are calculated on the basis of the most commonly used seed quantities per hectare, i.e. $65 \mathrm{~kg}$ for rice, $30 \mathrm{~kg}$ for maize and 10 $\mathrm{kg}$ for small cereals, as well as the planned seeding areas, based on trends over the past five years.

Post-harvest waste and losses there is no specific information on losses at the national level. Thus, based on the standard post-harvest loss rates in the region or in developing countries in general, the following rates are used: $15 \%$ for rice and maize, $10 \%$ for small grains and $25 \%$ for cassava (rates including losses from production, handling and storage).

Opening and closing stocks. Due to a lack of reliable data on stock levels, it is estimated that there will be no significant difference between stock levels at the beginning and end of the crop year. A very small replenishment of grain stocks is assumed, equivalent to the value of two weeks of indoor use.

Based on the above assumptions (table 1), total production for the upcoming marketing yearis estimated at 3,038 million tonnes of cereals (including milled rice and cassava in cereal equivalent). Total use is estimated at 3,481 million tonnes, suggesting an import requirement of 444000 tonnes of cereals, including 320000 tonnes of rice and 123000 tonnes of wheat. Grain import 
Table 1

Food balance for the marketing year 2018 (in thousands of tonnes)

\begin{tabular}{|c|c|c|c|c|c|c|c|}
\hline & $\begin{array}{c}\text { Rice } \\
\text { (factory) }\end{array}$ & Corn & $\begin{array}{c}\text { Sorghum, } \\
\text { millet, } \\
\text { other }\end{array}$ & Wheat & $\begin{array}{c}\text { Cereal } \\
\text { total }\end{array}$ & $\begin{array}{c}\text { Cassava } \\
\text { EqC }\end{array}$ & $\begin{array}{l}\text { Total in } \\
\text { equivalent } \\
\text { cereal }\end{array}$ \\
\hline $\begin{array}{l}\text { Availability } \\
\text { national } \\
\text { Production }\end{array}$ & $\begin{array}{l}1315 \\
1315\end{array}$ & $\begin{array}{l}652 \\
652\end{array}$ & $\begin{array}{l}685 \\
685\end{array}$ & $\begin{array}{l}0 \\
0\end{array}$ & $\begin{array}{l}2652 \\
2652\end{array}$ & $\begin{array}{l}385 \\
385\end{array}$ & $\begin{array}{l}3038 \\
3038\end{array}$ \\
\hline $\begin{array}{l}\text { Total use } \\
\text { Consumption } \\
\text { food } \\
\text { Forage use } \\
\text { Seed } \\
\text { requirements } \\
\text { Waste and losses } \\
\text { after harvest } \\
\text { Export } \\
\text { transboundary } \\
\text { usual } \\
\text { Stockpiling } \\
\text { increase (+) / } \\
\text { decrease (-) }\end{array}$ & $\begin{array}{c}0 \\
66 \\
197 \\
50\end{array}$ & $\begin{array}{c}65 \\
3 \\
98 \\
50\end{array}$ & $\begin{array}{c}34 \\
2 \\
68 \\
200\end{array}$ & $\begin{array}{l}0 \\
0 \\
0 \\
0\end{array}$ & $\begin{array}{c}3095 \\
2195 \\
\\
99 \\
70 \\
363 \\
300\end{array}$ & $\begin{array}{c}97 \\
0 \\
97 \\
0\end{array}$ & $\begin{array}{c}196 \\
704 \\
60 \\
\\
300\end{array}$ \\
\hline $\begin{array}{l}\text { Import } \\
\text { requirements } \\
\text { Import } \\
\text { commercial } \\
\text { planned } \\
\text { Food needs no } \\
\text { Cutlery }\end{array}$ & $\begin{array}{l}320 \\
300\end{array}$ & $\begin{array}{l}0 \\
0\end{array}$ & $\begin{array}{l}0 \\
0\end{array}$ & $\begin{array}{l}123 \\
100\end{array}$ & $\begin{array}{l}444 \\
400\end{array}$ & $\begin{array}{l}0 \\
0\end{array}$ & $\begin{array}{l}444 \\
400\end{array}$ \\
\hline
\end{tabular}

requirements are expected to be higher than the 412000 tonnes of grain imported in 2017.

Given the global health crisis the country's export earnings could be significant and jeopardize the country's ability to finance increased grain import needs. Given the expected slowdown in GDP growth of $2,1 \%$ (from $4,5 \%$ to $0,5 \%$, according to a World Bank study) a sharp decline in export earnings from commercial crops, commercial imports of rice (300 000 tonnes) and wheat (100 000 tonnes) are expected to remain at 2017 levels. However, they are expected to be below the 512000 tonnes imported so far in 2020, a level higher than usual import levels, probably to cope with the anticipated impact of the ongoing health crisis.

Thus, the total production in 2018 would be more than 900000 tonnes of pure rice, almost 1100000 tonnes of cassava, more than 500000 tonnes of corn and 200000 tonnes of peeled peanuts, more than 72000 tonnes of yam and 24200 tonnes of potatoes. However, these figures seem to be overstated in view of the difficulties faced by consumers in providing adequate nutrition, and contradict the data on imports (30\% of consumption), which usually indicate that domestic production is not able to fully meet the needs of the country. The share of local rice production in the market is about 25-30\% of the available rice (estimated by the Ministry of Agriculture) [4].

Goods traded between the various countries of the sub region (the main trading centres of Guinea) are not tracked at land borders and are therefore difficult to quantify, despite the presence of customs authorities. Guinea, by its geographical location, is also a transit country and the site of many sub regional trade, for example (fig. 2): 


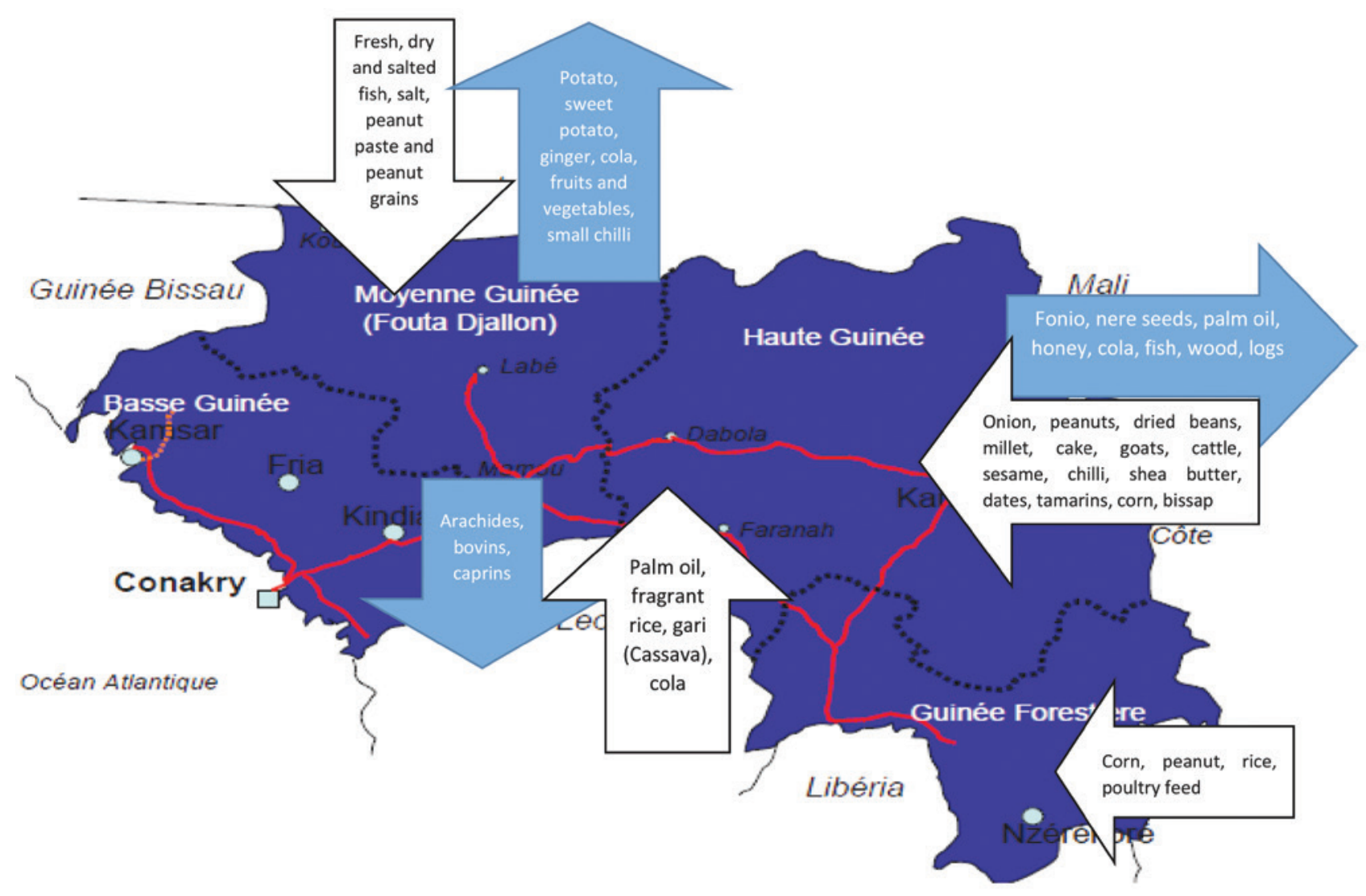

Fig. 2. Map of export flows in the sub region

- goods from Niger and Burkina Faso via Mali to Sierra Leone and Liberia;

- products from Sierra Leone, Liberia, Ivory Coast, Senegal, Gambia, Mali and Guinea-Bissau.

The volume of exports can be roughly estimated from various documentary sources, but this estimate is certainly not true, at least for some products.

The main region that provides more food is therefore Forest Guinea (table 2), which contributes $38 \%$ to national rice production. These are mainly rain-fed crops (hillside rice), although the region has low-lying potential, but little developed. Forest Guinea is also the main palm oil production region (South of Macenta, N'zerekore, and Yomou) and is said to have a development potential that is still largely underexploited. It is, on the other hand, the most remote region from the main urban centres, in particular Conakry.

\section{Contribution of Forest Guinea to the national food product market}

\begin{tabular}{|c|c|}
\hline Speculation & $\begin{array}{c}\text { Contribution to national } \\
\text { production (\%) }\end{array}$ \\
\hline Rice & 38 \\
\hline Cassava & 10 \\
\hline Peanuts & 7 \\
\hline Fonio & 5 \\
\hline Corn & 3,5 \\
\hline
\end{tabular}


Table 3 Lower Guinea has market potential and

Contribution of Maritime Guinea to the national food product market

\begin{tabular}{|c|c|}
\hline Species & $\begin{array}{c}\text { Contribution to national } \\
\text { production (\%) }\end{array}$ \\
\hline Pineapple & 97 \\
\hline Sweet banana & 60 \\
\hline Peanut & 37 \\
\hline Mango & 35 \\
\hline Rice & 27 \\
\hline Cassava & 13 \\
\hline Fonio & 9 \\
\hline Corn & 7 \\
\hline
\end{tabular}

Table 4

\section{Contribution of Upper Guinea to the national food product market}

\begin{tabular}{|c|c|}
\hline Species & $\begin{array}{c}\text { Contribution to national } \\
\text { production (\%) }\end{array}$ \\
\hline Cotton & 95 \\
\hline Yam & 95 \\
\hline Cassava & 43 \\
\hline Fonio & 37 \\
\hline Peanut & 35 \\
\hline Corn & 30 \\
\hline Rice & 25 \\
\hline
\end{tabular}

therefore has significant agricultural potential (mangroves) (table 3). It contributes $27 \%$ to national production. Mangrove rice production is the majority in Maritime Guinea. The main assets of this region are its proximity to Conakry and therefore an important area of consumption and its potential for agricultural development.

Upper Guinea has a $25 \%$ contribution to national food production (table 4). The Faranah region is the most important production area in Upper Guinea. It would appear that locally produced rice is mainly destined for local markets and is relatively little subject to inter-regional trade. It is, on the other hand, the first yam production region (Kankan), which it supplies $75 \%$ of the volumes marketed on the national market.

Upper Guinea is also an important breeding region. Its cattle represent $34 \%$ of the national livestock, sheep $25 \%$ and goats $17 \%$.

Average Guinea has $14 \%$ of the national potential (table 5). Rice production is marginal in the natural region of Middle Guinea (10\% of national production) and is concentrated in the plains of the Prefectures of Gaoual and Koundara. The agricultural production of the region is rather oriented towards vegetable crops (onion, chili, tomatoes...) and on animal husbandry in the Piedmont. It is also the first potato production region.

Table 5

\section{Contribution of Average Guinea to the national food product market}

\begin{tabular}{|c|c|}
\hline Species & $\begin{array}{c}\text { Contribution to national } \\
\text { production (\%) }\end{array}$ \\
\hline Potatoes & 98 \\
\hline Onion & 60 \\
\hline Corn & 56 \\
\hline Rice & 10 \\
\hline Fonio & 50 \\
\hline
\end{tabular}


As Guinea's ecosystems are highly contrasted, national food production is characterized by its geographical breakdown. Each natural region thus has its own food specificities (table 6, fig. 3).

In the Guinean food market, there is a tendency to develop and increase consumption (table 7). The market capacity is increasing. The food market in Guinea is characterized as one of the fastest growing among all food products. The market volume of food and sea delicacies is about 3 thousand tonnes per year, and it is far from saturation. The official volume of imported products is about 19 thousand tonnes or 114 billion GNF. The volume of exports of products is about 9 thousand tonnes or 66 billion GNF $[2,3]$.

The road to Conakry has a lot of traffic. From the capital of Guinea, 30-35-ton trucks arrive daily, with flour, rice, sugar, onions, palm oil, etc. rice, which is the first most consumed food item, which accounts for $50 \%$, is imported; to countries such as China, India; and Bangladesh, which refills from Guinea with imported rice. Despite the presence of local rice. Imported rice remains the most consumed by the Guinean population. Sugar also remains widely consumed, and the Guinean market is served by countries such as Mexico, Cuba, and Guatemala.

Food production systems in Guinea

\begin{tabular}{|c|c|c|}
\hline $\begin{array}{l}\text { Natural } \\
\text { region }\end{array}$ & $\begin{array}{l}\text { Region } \\
\text { admini- } \\
\text { strative }\end{array}$ & $\begin{array}{l}\text { Agricultural food } \\
\text { production systems on the } \\
\text { market }\end{array}$ \\
\hline $\begin{array}{l}\text { Guinea } \\
\text { Maritime }\end{array}$ & $\begin{array}{l}\text { Boke } \\
\text { Kindia }\end{array}$ & $\begin{array}{l}\text { Crop systems based on } \\
\text { mangrove rice, partly in } \\
\text { managed areas, hillside crops } \\
\text { in the hinterland, main crops } \\
\text { are rice, peanuts, fruits and } \\
\text { vegetables }\end{array}$ \\
\hline $\begin{array}{l}\text { Middle } \\
\text { Guinea }\end{array}$ & $\begin{array}{l}\text { Mamou } \\
\text { Labé }\end{array}$ & $\begin{array}{l}\text { Crops of corn, okra, taro and } \\
\text { potatoes in the tapades, } \\
\text { fonio, peanut and rice on the } \\
\text { outdoor fields resting on the } \\
\text { burn, area of predilection } \\
\text { of cattle, sheep and goat, } \\
\text { vegetable crops }\end{array}$ \\
\hline $\begin{array}{l}\text { Upper } \\
\text { Guinea }\end{array}$ & $\begin{array}{l}\text { Faranah } \\
\text { Kankan }\end{array}$ & $\begin{array}{l}\text { Rice crops on large } \\
\text { floodplains and tubers, cattle } \\
\text { breeding, cotton cultivation }\end{array}$ \\
\hline $\begin{array}{l}\text { Forest } \\
\text { Guinea }\end{array}$ & N'Zerekore & $\begin{array}{l}\text { Perennial crops such as } \\
\text { coffee, palm, cocoa, rubber, } \\
\text { lowland rice, tubers, pig } \\
\text { breeding }\end{array}$ \\
\hline
\end{tabular}

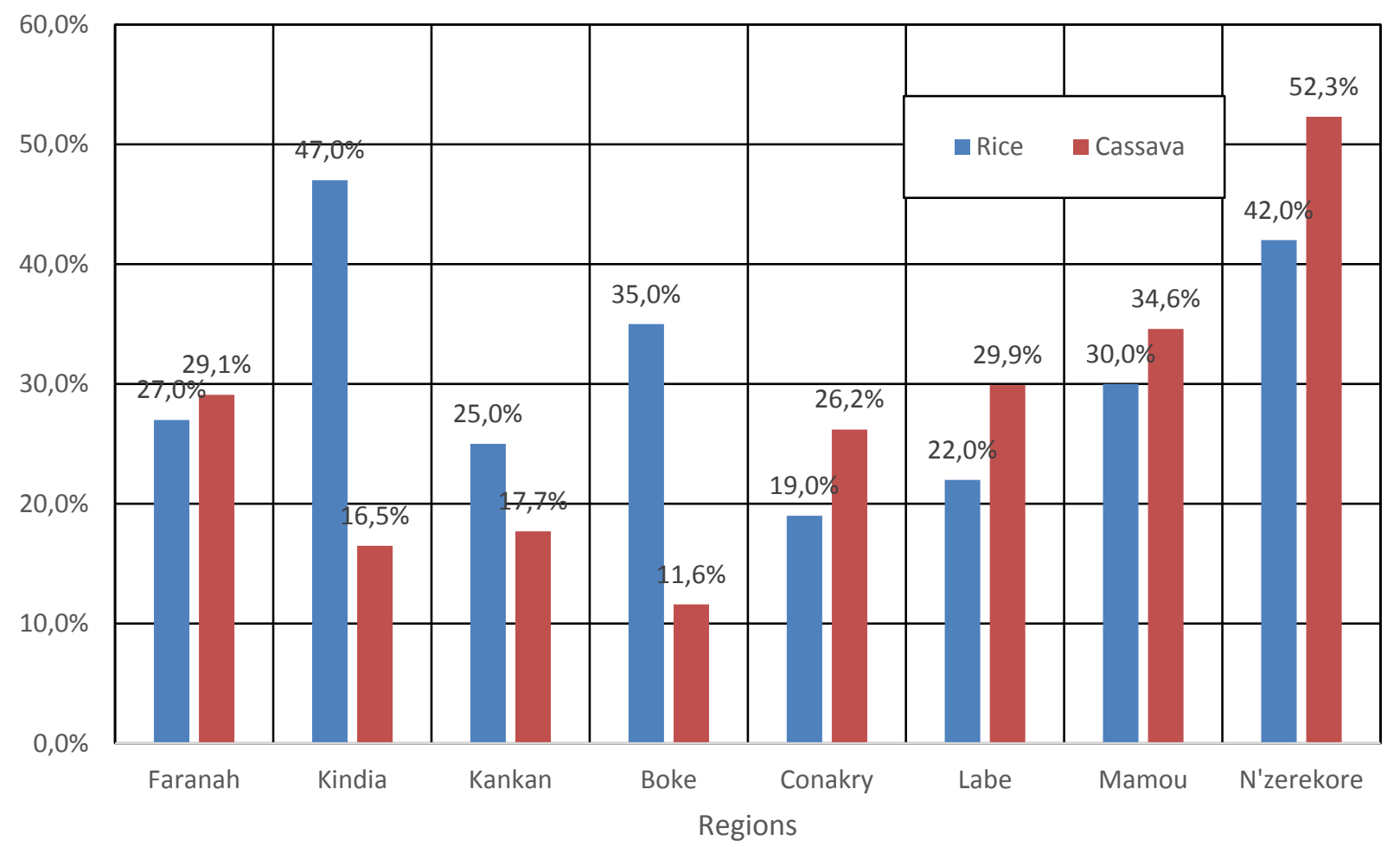

Fig. 3. Food consumption statistics by region administrative of Guinea, 2019 


\section{TPAHCПOPT/TRANSPORT}

The palm oil consumed in Guinea comes from countries such as Nigeria and Indonesia. Guinea feeds onions to countries in the African sub-regions like Nigeria, Mali, Cameroon, Senegal, Niger, Chad, etc. and also to China. For flour, the Guinean market remains one that can be dominated by countries such as Russia, Argentina and Turkey. The price of flour imports will decrease since the establishment of a flour mill in the Guinean capital. Imports of all these food products, except rice, have been declining for several years between 2015 and 2019 thanks to the government's policy of promoting local food products, such as "consume Guinea" (fig. 4, 5).

The main imported food products in Guinea Conakry 2015-2019 (thousands of tonnes) [1].

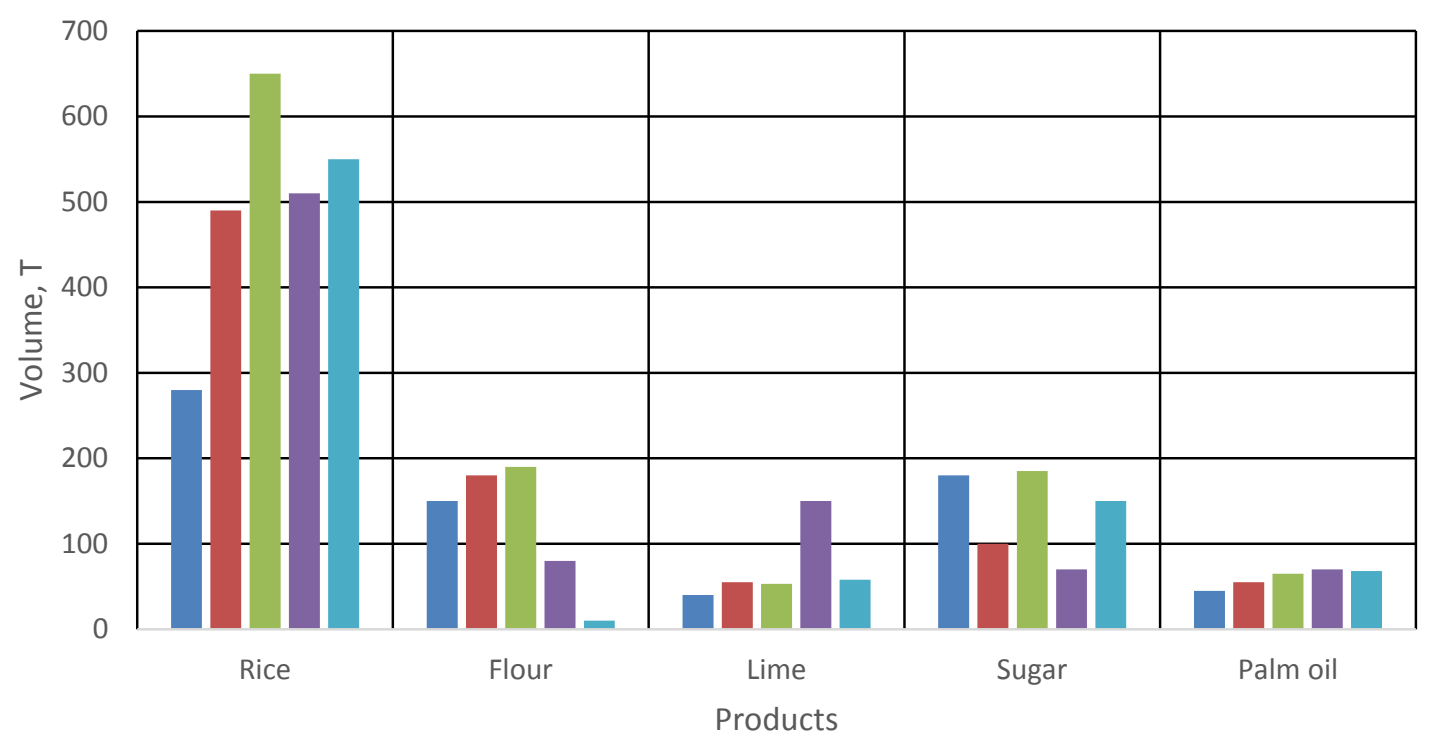

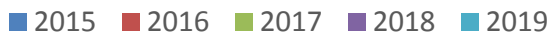

Fig. 4. Analysis of the supply of food imports to Guinea

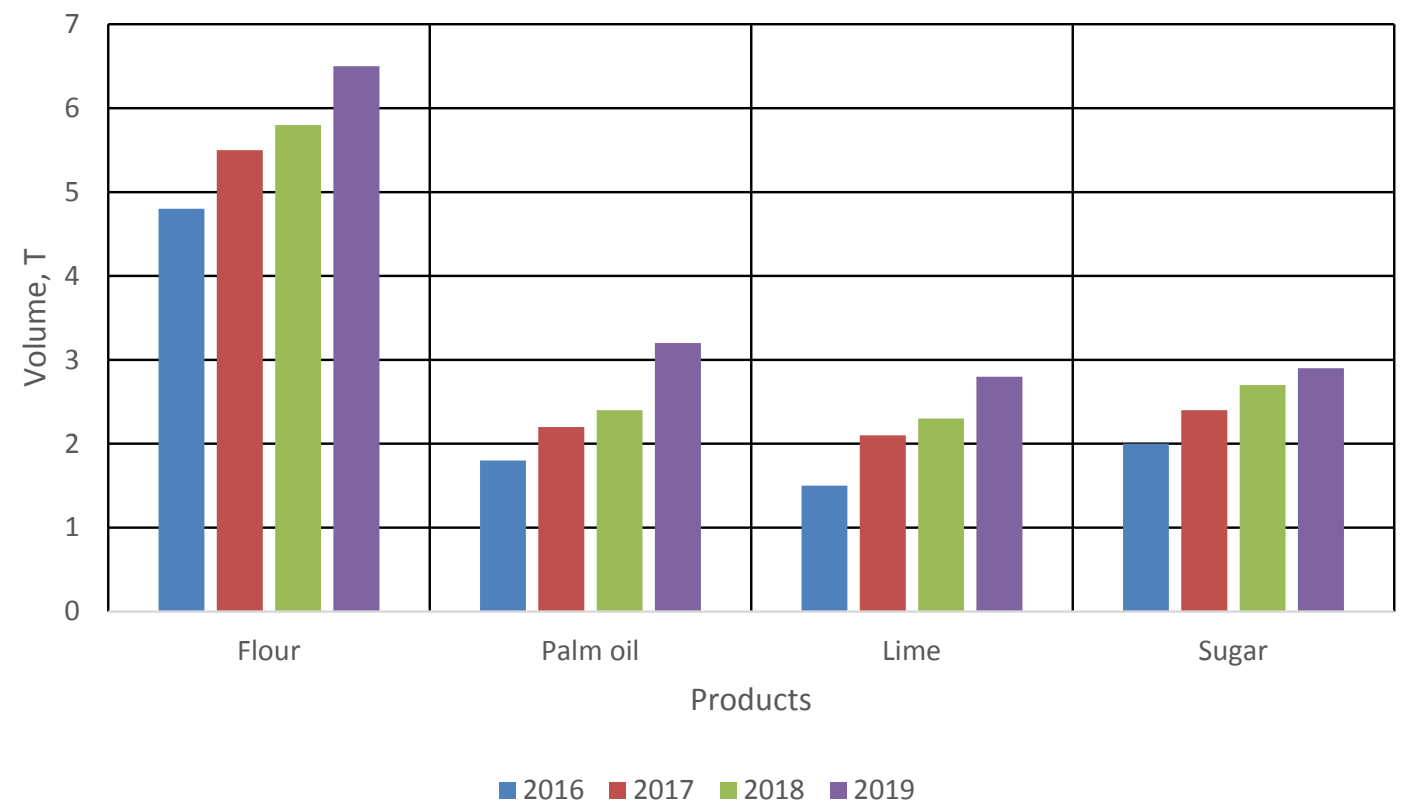

Fig. 5. Food export statistics in Guinea 
Table 7

Guinea Food Market Index 2019, \%

\begin{tabular}{|l|c|}
\hline \multicolumn{1}{|c|}{ Food products on the market } & $\begin{array}{c}\text { Production } \\
\text { index level }\end{array}$ \\
\hline Grain and grain products market & 106,1 \\
\hline Milk and dairy products market & 102,9 \\
\hline Potato and fruit and vegetable market & 103,1 \\
\hline Vegetable Oil Market & 106,7 \\
\hline Fish and Seafood Market & 100,4 \\
\hline Market bananas, tangerines, avocados & 106,0 \\
\hline Cassava, yam, peanut market & 109,7 \\
\hline Rice, corn, fonio market & 109,7 \\
\hline Market beans, mango, orange & 102,7 \\
\hline $\begin{array}{l}\text { Market cashews, coconuts, palm nuts, } \\
\text { sweet potatoes, onions, tomatoes, etc. }\end{array}$ & 104,4 \\
\hline
\end{tabular}

The company Africa Logistics subsidiary in Kessler is engaged in the transportation of products to Guinea This Company can transport 5 types of production, such as: steamed, vegetables, chilled, square gift. The fleet includes vehicles with a load capacity from 1,5 tonnes to 20 tonnes. The cost of 1 hour, a car with a load capacity of 1,5 tonnes, inside Guinea outside the MKAD, the cost is not for hours, but for kilometres. Thus, 1 kilometre in Conakry.

Diesel fuel - the cost of diesel fuel per mileage.

30 litres per $75 \mathrm{~km} 12000 / 75 \times 30 \times 900$ GNF per litre $=4320000 \mathrm{GNF}$.

Rubber 10 pcs. $\times 20000 \mathrm{GNF}=200000 \mathrm{GNF}$ (this is the cost of tires for the specified mileage).

5,5 times $\times(300 \mathrm{GNF} \times 50$ litres $)=82500 \mathrm{GNF}$ (the cost of changing the oil for the race).

Fuel filter $=13$ times $\times 15000 \mathrm{GNF}=195000 \mathrm{GNF}$.

Oil filter $=5,5$ times $\times 4000 \mathrm{GNF}=22000 \mathrm{GNF}$.

Repair funds-this includes repair and replacement of consumables. $4000 \mathrm{GNF}$ for $8000 \mathrm{~km} / \mathrm{h}$.

$120000: 4000 \times 8000=240000$ GNF.

Depreciation of fixed assets. Deterioration of the semi-trailer.

1 : 30 months $\times 100 \%=0,03 \%$ - monthly depreciation rate (30 months is the useful life of the vehicle).

(1 50000 hitch price $\times 0,03: 100$ ) monthly deductions $\times 12=540000$ GNF. Within a year.

Total: 405 GNF per $1 \mathrm{~km} / \mathrm{h}$.

Employee fees (driver):

The salary is $5 \mathrm{GNF} / \mathrm{km} / \mathrm{h}$.

Payroll deductions $25 \%=3 / 100 \times 25=0,75 \mathrm{GNF}$ $\mathrm{km} / \mathrm{h}$.

Business travel 105 GNF per day $\times 253$ working days $=$ 26565 GNF.

Total: 7,96 GNF per $1 \mathrm{~km} / \mathrm{h}$.

Analysis of the food market in recent years shows systemic processes of disruption. Changes occur in the change of ownership, the format of sales, the range itself. Starting in the 2010s, the industry experienced a marked expansion of the retail network, which then took a leading position in the market, effectively leaving behind small and medium-sized entrepreneurs. The structure of Food retail enterprises in 2020 is presented.

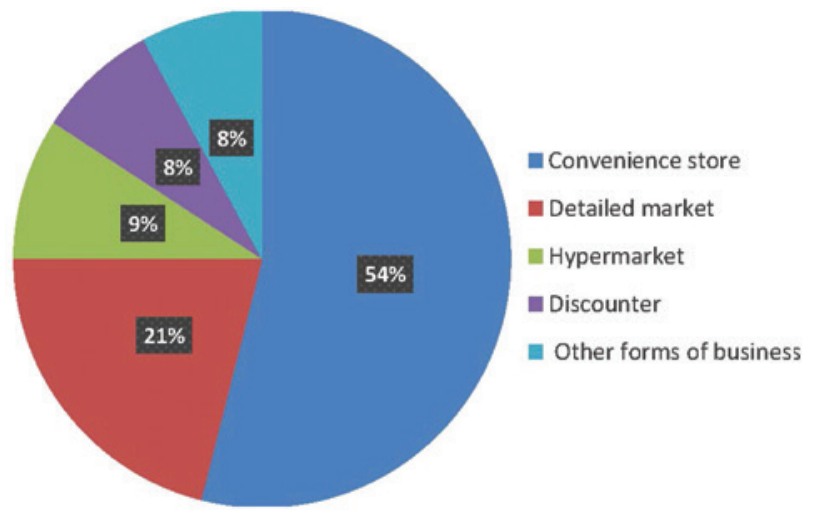

Fig. 6. Structure of food retailers in Guinea in 2020

A feature of the modern Guinean food market is the rapid growth of food home stores. As the figure shows on fig. 6 , they already occupy the first place in the structure of the main market players.

The preferences of the population. Of these, a sufficient range of food products, and its relatively affordable price. Being by far the most preferred type of grocery store, home stores operate in economy supermarket mode, gradually moving to home store hard status. The second place in the ranking structure of the grocery store remains for hypermarkets, but since 2016, the share of this type 
of stores in the market is constantly decreasing. For 2020 , they remain no more than $23 \%$. The third place behind supermarkets, conveniently located within the city limits. For the year 2020, their share stopped at $15 \%$. Discos especially in the network format, gain confidence trade, approaching $10 \%$. One tenth of the market remains behind the street trade, small private shops.

Analysis of the retail market of food products in the Republic of Guinea indicates the presence in the industry of a number of factors: the negative dynamics of the prices of the national currency.

At the same time, Guinean food market statistics clearly show a positive dynamics of sales volumes in the segment of large chain stores. However, the analysis of the agricultural products market indicates a clear increase.

\section{Surplus production areas}

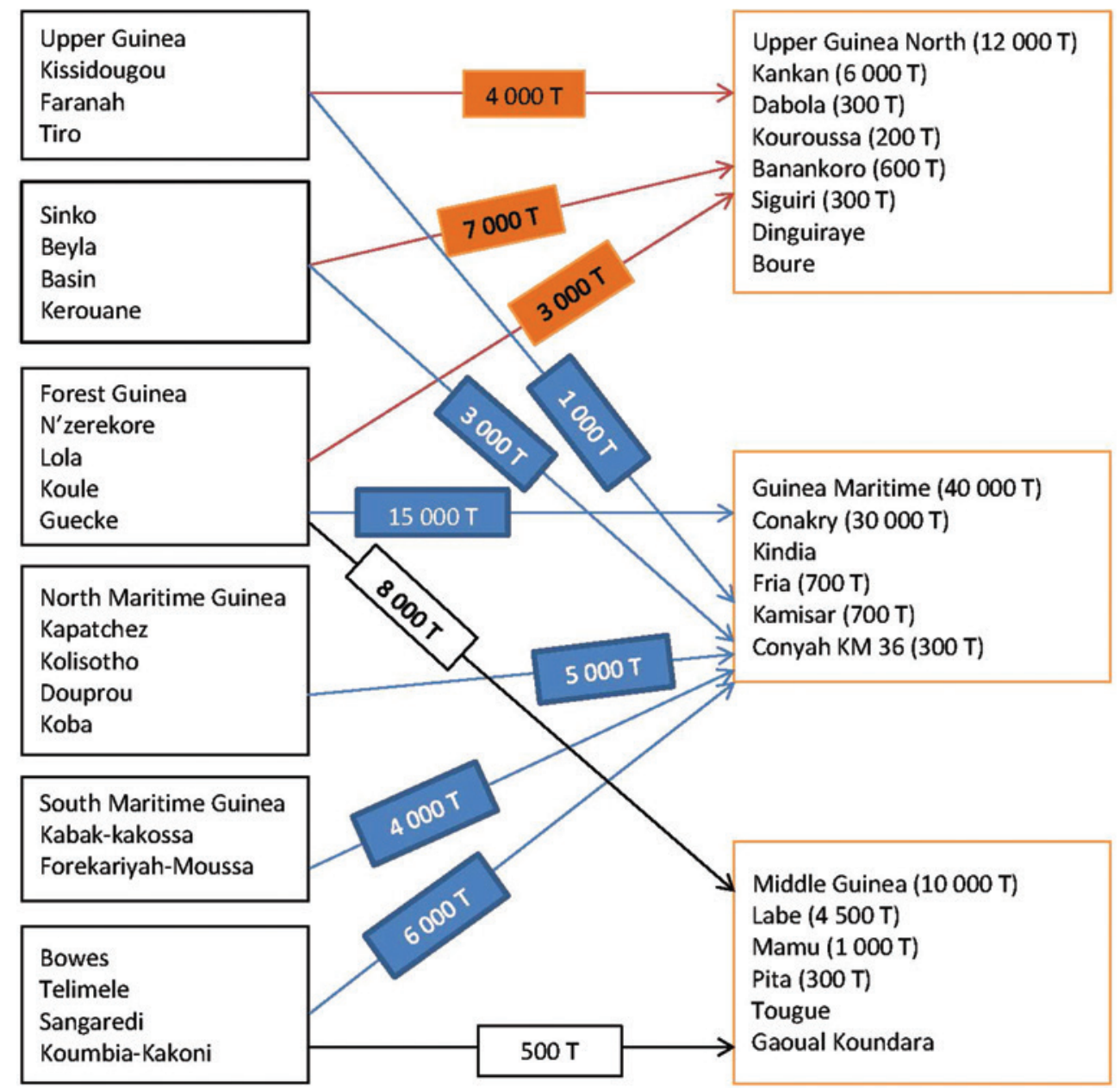

Fig. 7. Main areas of food suppliers and consumers in the Republic of Guinea (proposed food marketing scheme)
Economic indicators of food trade are systematically taken into account in consolidated macroeconomic reports. The market showed sustained growth in 2019. Trade in food, including beverages, and tobacco products has continued to grow each year since 2000. The industry is also growing in quarterly terms. In the first quarter, the retailer sold 2571 billion GNF, in the third 7299 billion GNF [3, 4].

Over a longer period, the retail food market experienced a slowdown in growth. While in 2012, the market increase was $15,5 \%$ compared to last year, it increased by less than $7 \%$ in 2019. At the same time, analysts give favourable forecasts: already in the fourth quarter should increase the growth rate to $8 \%$.

\section{Consumption areas}

Upper Guinea North (12000 T) Kankan (6 000 T)

Kouroussa $(200 \mathrm{~T})$

$600 \mathrm{~T}$

Dinguiraye

Boure

Kindia

Fria (700 T)

Kamisar (700 T)

Conyah KM 36 (300 T)

Pita (300 T)

Tougue

Gaoual Koundara 
Customer demand expressed calculation and rationality when performing expenses. The cost of life means that the population, on the one hand, should reduce consumption. On the other hand, the market flow of parties interested in food quality.

Thus, maintaining the position in the market is achieved by meeting the preferences of the buyer, fighting for the best places to place outlets.

At present, the issue of product quality is acute. After the introduction of the COVID-19 health crisis, the Guinean market felt a shortage of food, which should have covered domestic producers. Temporary interruptions in the range are closed by increasing the supply volumes of partner bases or placing orders.

\section{Features of fruit transportation by road}

- Cargo characteristics. Fruit is a very capricious cargo. The slightest mistake in setting the temperature can lead to their damage. The same applies to mechanical damage and ordinary shaking on road bumps. It should be borne in mind that for each crop, even for different varieties of apples, there is its own optimal temperature and humidity.

- Vehicle requirements. Transportation of fruits is carried out in special insulated or refrigerated vans. Some customers, in order to save money, order ordinary trucks, for example, to transport boxes of tangerines in the New Year's season. However, in this case, the carrier is not responsible for the freshness of the cargo.

- Loading/unloading requirements. When loading, it is important to pay special attention to the packaging of fruits. As a rule, these are boxes laid with sawdust or paper. At the same time, the softer and more mature fruits should lie on top, and the denser ones should lie on the bottom. Install the boxes in the van is not tight, with gaps between the rows for the circulation of fresh air. By the way, it is worth considering that some fruits cannot be transported with other crops due to the high percentage of ethylene released. This element causes accelerated maturation and, as a result, putrefaction.
Transportation requirements. Fruits are considered food products, so there are special requirements for their transportation. In particular, it is necessary to draw up a number of accompanying documents and comply with sanitary standards.

- Certain types of food products for which there are rules for the transport of perishable goods can be assigned to the regions of Guinea in accordance with the proposed food marketing scheme are shown in fig. 7.

Depending on the conditions of transportation that do not require specialized rolling stock, requiring compliance with special sanitary and temperature regimes, therefore, specialized rolling stock, taking into account the characteristics of the cargo of food goods

But in the classification of perishable goods, the signs of the origin of the goods and the associated classification by heat treatment should remain dominant. According to the rules for the transportation of perishable goods by road in international domestic traffic, perishable goods, depending on their origin, are divided into the following groups:

- plant products: fruits, vegetables, berries, mushrooms;

- products of animal origin: meat of various animals and birds, fish, caviar, milk, eggs;

- processed products: dairy products, incl. cheeses, various fats, sausages and other meat products, frozen fruits, etc.;

- live plants: cut flowers, potted flowers, seedlings of trees and shrubs, seedlings.

According to the method of heat treatment, perishable foodstuffs are divided into:

- fresh or cooled without changing their natural state;

- refrigerated (as a rule, at temperatures from $-6^{\circ} \mathrm{C}$ to $+4{ }^{\circ} \mathrm{C}$, but sometimes up to $+13^{\circ} \mathrm{C}$ );

- frozen (temperature from $-7^{\circ} \mathrm{C}$ to $-18^{\circ} \mathrm{C}$ );

- frozen (temperature below $-18^{\circ} \mathrm{C}$ ).

When transporting perishable foodstuffs, the following conditions must be met:

- the floor of the cargo space must be cleaned, 
the floor is not allowed;

- perishable goods made of briquettes must be of the correct rectangular shape without cellophane or ice;

- $\quad$ some types of products (liver, lungs, kidneys) should be separated from each other by wooden shields up to the height of the briquettes;

- it is forbidden to transport different types of products of animal origin in the same cargo space;

- delivery of products to destinations must be carried out within a strictly specified time;

- heated (with a higher temperature compared to the temperature of the outside air).

\section{Conclusions}

At present, the organization and improvement of food transport remains a thorny problem in Guinea, but for optimization of this transport passes the resolution to reduce the cost of transport while choosing optimal route for an efficient route and supply markets of Guinea has a record time.

The organization and improvement of food transport remains a thorny problem in Guinea, but for optimization of this transport passes the resolution to reduce the cost of transport while choosing optimal route for an efficient route and supply markets of Guinea has a record time.

However, in the last decade, Guinea has seen a constant increase in the interest of structures in the theory and practice of logistics, which in the developed countries of the world has long been practical. This is due to the fact that logistics technologies can achieve significant competitive advantages [5]. They ensure the delivery of the right product in the right quantity and quality to the right place and time to a specific consumer at the optimal cost [6-11]. The implementation of such a seemingly simple rule allows for a $25-45 \%$ reduction in all types of inventory of material resources, lower production costs, and accelerates the turnover of the working capital of the enterprise $[9,12]$.

In the struggle for competition in the international transport services market, Guinea has a good starting position and the advantages of a geographical location on the African continent. Thus, one of the key links in the development of the Guinean economy is the modernization of the transport system and the realization of a powerful potential.

\section{References}

1. Vehicle Registration Service of the Ministry of Transport of Guinea. (In French). Available at: https:// www.agenceecofin.com/transports

2. National Statistical Institute of the Republic of Guinea. (In French). Available at: https://www.statguinee.org

3. Le Coz, F., \& Broutin, C. (2009). Convergences et conflits d'intérêt entre les paysans et les consommateurs: l'exemple de la Guinée: Peut-on surmonter les conflits et renforcer les convergences? Rapport final. Paris, Gret, Pôle AAD Publ., 77 p. (In French). Available at: rap-etude-guinee cfsi-gretok.pdf - https:// www.cfsi.asso.fr

4. Cour, J.-M., \& Snrech, S. (2010). Preparing for the Future a vision of West Africa in the year 2020. West Africa Long-Term Perspective Study. Paris, OECD Publ., 156 p. (In English). Available at: https://www. oecd.org/swac/publications/38512525.pdf

5. Velmozhin, A. V., Gudkov, V. A., Mirotin, L. B., \& Kulikov, A. V. (2016). Gruzovye avtomobil'nye perevozki: uchebnik dlya vuzov. 3rd edition, revised. Moscow, Goryachaya liniya - Telekom Publ., 560 p. (In Russian).

6. Mirotin, L. B., \& Nekrasov, A. G. (2003). Logistika integrirovannykh tsepochek postavok. Moscow, Ekzamen Publ., 254 p. (In Russian).

7. Nekrasov, A. G., Beliaev, V. M., Mirotin, L. B., Volkov, V. D., \& Spirin, I. V. (2017). Logistics engineering for road transport. Vestnik Moskovskogo avtomobilno-dorozhnogo gosudarstvennogo tehnicheskogo universiteta (MADI), 1(48), pp. 3-12. (In Russian). 
8. Nikolin, V. I., Vitvitskiy, E. E., \& Mochalin, S. M. (2004). Gruzovye avtomobil'nye perevozki. Omsk, VariantSibir' Publ., 480 p. (In Russian).

9. Vitvitskiy, E. E. \& Yur'eva, N. I. (2012). Praktika operativnogo planirovaniya zatrat na perevozku gruzov v gorodakh. The Russian Automobile and Highway Industry Journal, 6(28), pp. 18-25. (In Russian).

10. Kulikov, A. V., Firsova, S. Yu., \& Sovetbekov, B. (2019). Perfection the organization of transportation of export grain. Herald of KRSU, 19(4), pp. 46-52. (In Russian).

11. Firsova, S. Yu., Kulikov, A. V., \& Sovetbekov, B. (2019). Rol' transportnoy logistiki v obespechenii ekzistentsional'noy bezopasnosti cheloveka. Herald of KRSU, 19 (8), pp. 97-101. (In Russian).

12. Kulikov, A. V., \& Firsova, S. Y. (2019). Effectiveness of road transport technology in modern housing systems. Proceedings of the 5th International Conference on Industrial Engineering (ICIE 2019), Vol. II, part 2, March, 25-29, Sochi. Cham (Switzerland), Springer International Publ., pp. 813-821. (In English). DOI: $10.1007 / 978-3-030-22063-1 \_8$

\section{Information about the authors}

Mohamed Kuruma, Master's Student at the Department of Road Transport, Volgograd State Technical University, e-mail: kouroumamohamed074@gmail.com

Alexey V. Kulikov, Candidate of Engineering, Associate Professor at the Department of Road Transport, Volgograd State Technical University, e-mail:v2xoda@ya.ru

\section{Сведения об авторах}

Курума Мохамед, магистрант кафедры автомобильных перевозок, Волгоградский государственный технический университет, e-mail: kouroumamohamed074@gmail.com

Куликов Алексей Викторович, к. т. Н., доцент кафедры автомобильных перевозок, Волгоградский государственный технический университет, e-mail:v2xoda@ya.ru

For citation: Kuruma, M., \& Kulikov, A. V. (2021). Improving the organization of food transportation by road to shopping centres in Conakry (Guinea) by optimizing supply chains. Arkhitektura, stroitel'stvo, transport [Architecture, construction, transport], (2), pp. 76-89. (In English). DOI: 10.31660/2782-232X2021-2-76-89.

Для цитирования: Kuruma, M. Improving the organization of food transportation by road to shopping centres in Conakry (Guinea) by optimizing supply chains / M. Kuruma, A. V. Kulikov. DOI: 10.31660/2782232X-2021-2-76-89. - Текст : непосредственный // Архитектура, строительство, транспорт. - 2021. № 2. - C. 76-89. 